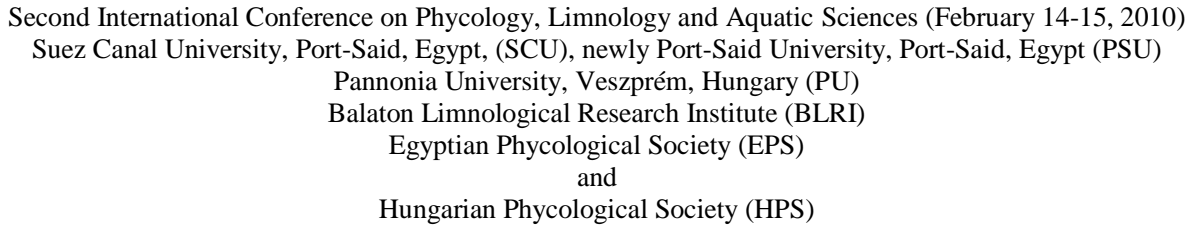

\title{
MARINE ALGAL SURVEY OF DERNA, SUSA AND TOLMETA AT LIBYA COASTS
}

\author{
Alaa. A. Said ${ }^{1}$; Massoud M. Godeh ${ }^{2}$ and Fathalla O. El-Menifi ${ }^{2}$ \\ ${ }^{1}$ Botany Department, Faculty of Science, Zagazig University, Egypt \\ ${ }^{2}$ Botany Department, Faculty of Science, Garyounis University, Benghazi, \\ Libya
}

\begin{abstract}
Sixty one of the marine macroalgal species (39 genera) were collected and identified from three coasts: Derna, Susa and Tolmeta;-which lie to the eastern of the Libyan coast. Twenty one species of these algae (34.43\%) belonged to 13 genera of Chlorophyta, Twenty species of them (32.79\%) belonged to 9 genera of the Phaeophyta, and twenty species $(32.79 \%)$ belonged to 17 genera of the Rhodophyta; with a clear dominance of Cystoseira species. The relatively richest coast was Susa which has 38 algal species. Tolmeta coast comes at the second rank with 33 algal species while the poorest one was Derna coast with 12 species only (none of them belonged to Phaeophyta). The ecological status of marine surface waters and its purity could be arranged according to the species enrichment index of these coasts as follows: Susa > Tolmeta > Derna. The three coasts shared together only three green species and one red species (Hypnea musciformis). The similarity indices were $24 \%$ and $26.67 \%$ between Derna coast and both of Susa and Tolmeta, respectively. Meanwhile, the highest similarity value was (57.14\%) between Susa and Tolmeta coasts.
\end{abstract}

Key words: Marine algae, Chlorophyta, Phaeophyta, Rhodophyta, Species richment index, Similarity index.

\section{Introduction}

Marine macroalgae have very economic potential as fodder, fertilizers, fuel, chemicals and medicine (Critchley et al., 1998; Dawes, 1998; Faulkner, 2002 and Haefner, 2003) and antimicrobial activity (Hafez et al., 2005; El-

* The corresponding author: On leave from Zagazig University, Egypt.

(ISSN: 1110-8649) alaasaidalaasaid@yahoo.com 
Gahmy, 2007 and El-Fatemi, 2008). It is rich sources of nutritive materials, structurally novel and biologically active metabolites used in many new pharmaceutical industries (Lima-Filho et al., 2002; Ely et al., 2004 and Inci $\boldsymbol{e t}$ al., 2006). It contains high amounts of carbohydrates, protein and minerals (Ruoe'rez and Saura-Calixto, 2001). At least 500 of macroalgae are suitable for indirect and direct nutrition for human and fish (Linda and Lee, 2000) and others used as ecological and biological indicators of water quality (Pinedo et al., 2007). Libya has a very long coast extending over $1935 \mathrm{Km}$. south the Mediterranean Sea at the eastern north part of Africa. It is rich by economically important marine algal species. Many new species of marine algae at eastern Libyan coast recorded by Nizamuddin et al. (1979), Nizamuddin and Godeh $(1989,1990$ a, b \& c and 1993) and Nizamuddin and El-Menifi (1993).

There are little recent literatures about the marine algae of Libyan coast. Ardissone (1893) made the first Italian list of Libyan marine algae while, the last list of Libyan marine algae (168 species) was made by Godeh et al. (1992). Therefore, more researches still needed for harvesting, identifying and evaluating the Libyan marine algae. From 2007 till now, the authors worked as a team and wrote a series of papers to assess these goals, and to assess the ecological status of marine surface waters and its antimicrobial activities.

\section{Material and Methods}

\section{The Study area:}

The geographical location of study area is illustrated in Figure (1). Derna located about $175 \mathrm{Km}$. western Tobruk coast at $32^{\circ} 45^{\prime} 18.70^{\prime \prime} \mathrm{N}$ and $22^{\circ} 38^{\prime}$ $17.80^{\prime \prime}$ E. It has a completely rocky shore with commercial port protected from winds and waves. The algae are mostly collected from the rocks at different depths and small sandy parts of shore. Susa coast extended $3 \mathrm{Km}$. and lies at $32^{\circ}$ 54' $45.01^{\prime \prime} \mathrm{N}$ and $21^{\circ} 58^{\prime} 31.07^{\prime \prime} \mathrm{E}$ about $90 \mathrm{Km}$ at the western of Derna. It is a protected shore with some small rocky islands.

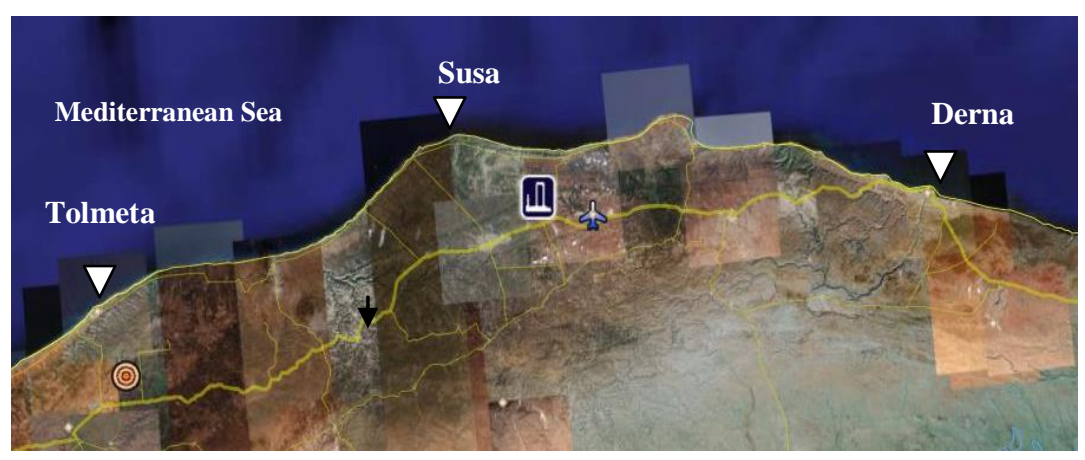

Figure (1): Map of the study area. 
The algae were collected from the rocks and about 4 meters depths. Tolmeta lies at $32^{\circ} 41^{\prime} 45.68^{\prime \prime} \mathrm{N}$ and $20^{\circ} 57^{\prime} 38.99^{\prime \prime} \mathrm{E}$, about $200 \mathrm{~km}$. at the western of Susa and about $190 \mathrm{Km}$. at the eastern of Benghazi. Their open rocky shore has some little sandy shores and some small rocky islands. It has also a small fishing port.

\section{Sampling and sample preparations:}

Specimens were harvested generally in the morning in ice tanks in polyethylene bags sprinkled with $4 \%$ formalin sea water for mounting on the herbarium sheets, glass bottles and some of them kept freshly at refrigerators for taxonomic identification using Italian list Ardissone (1893), Pampanini (1931), Burrows (1991) and Aleem (1993). Epiphytes, impurities and salts were removed carefully and quickly at laboratory with tap and distilled waters. The herbarium sheets have been deposited in the Herbarium, Department of Botany, Garyounis University, Benghazi $\{$ CHUG nos. FM. 650; 651\}. Longitudinal and transverse sections of the axis at the apexes, midfronds and the bases were manually made and stained in $1 \% \mathrm{KI}_{2}$ or anilin blue solution.

\section{Species richness:}

Species richness index calculated according to Wilhm (1975) by the direct counting of different algal species at every sampling site. The decrease in number of species and increase in number of individuals were characteristic features for the polluted water.

\section{Similarity index:}

The similarity was calculated as statistical parameter by the equation of Sorenson (1948) to assess the degree of similarity between algal species of the studied sites which, depends upon the presence or absence of different taxa:

$$
\mathrm{IS}_{\mathrm{s}}=(\mathbf{2 C} \times \mathbf{1 0 0}) / \mathrm{A}+\mathrm{B}
$$

Where: $\mathrm{IS}_{\mathrm{s}}=$ similarity quotient.

$\mathrm{C}=$ number of species common in both sites.

$A=$ number of species in the first site.

$\mathrm{B}=$ number of species in the second site.

\section{Results and Discussion}

Sixty one marine macroalgal species (39 genera) were identified at the study area with an agreement of the results of Diaz-Valdes et al. (2007) who identified 65 littoral macroalgae using them to assess the environmental quality of Valencian rocky coasts (SE Spain). Diapoulis and Tsiamis (2007) also found 88 marine benthic macroalgal taxa at the upper infralittoral zone of south Aegean Sea (Greece). Contrarily, Rhodes Island has a total of 155 macroalgal taxa (Tsiamis et al., 2007). 
Regarding to the algal divisions at the study area, chlorophyta was represented by 13 genera ( 21 species, Table 1$)$. The relatively richest coast with the green algae is Susa which had 18 species. Meanwhile Derna and Tolmeta coasts had 7 and 6 species, respectively. This is may be due to the presence of Caulerpales which considered as a strong competitors (David et al., 2004 and Piazzi et al., 2005) and its production of toxic substances, which inhibit their grazing (Piazzi et al., 2005).

Table (1): Distribution of green marine algae at Derna, Susa and Tolmeta.

\begin{tabular}{|c|c|c|c|}
\hline Algae & & Coast & \\
\hline Chlorophyta & Derna & Susa & Tolmeta \\
\hline Acetabularia acetabulum (linn.) Silva & - & + & + \\
\hline Anadyomene stellata (Wulfen) C. Agardh & + & + & + \\
\hline Bryopsis hypnoides Lamouroux & - & + & - \\
\hline Caulerpa prolifera (Forsskål) Lamouroux & + & - & + \\
\hline Chaetomorpha capillaries (Kütz.) Børgesen & - & + & - \\
\hline Cladophora pellucida (Huds.) Kützing & - & + & - \\
\hline Cladophora prolifera (Roth) Kützing & - & + & - \\
\hline Cladophora pseudopellucida Vanden Hauk & - & + & - \\
\hline $\begin{array}{l}\text { Cladophoropsis modonensis } \quad \text { (Kütz.) } \\
\text { Reinbold }\end{array}$ & - & + & - \\
\hline Cladophoropsis (Kütz.) Børgesen Reinbold & - & + & - \\
\hline Codium corymbosum Nizamuddin & - & + & - \\
\hline Codium tomentosum (Huds.) Stackhouse & - & + & - \\
\hline Codium coralloides (Kütz.) C. Agardh & - & + & - \\
\hline Codium decorticatum (Woodw.) Howe & - & + & - \\
\hline Dasycladus vermicularis (Scopoli) Krasser & + & + & + \\
\hline Enteromorpha linza (Linnaeus) J. Agardh & + & - & - \\
\hline Flabellia petiolata (Turra) Nizamuddin & - & - & + \\
\hline Halimeda tuna (Ellis et Solander) Lamouroux & + & + & + \\
\hline Ulva lactuca Linnaeus & - & + & - \\
\hline Ulva rigida C. Agardh & + & + & - \\
\hline Ulva reticulata Forsskål & + & + & - \\
\hline Number of genus & 6 & 10 & 6 \\
\hline Number of species & 7 & 18 & 6 \\
\hline
\end{tabular}

+: present $\quad-:$ absent

Phaeophyta (Table 2) was represented by 9 genera (20 species) with clear dominance of ten Cystoseira species, where its assemblages are very good ecological and biological indicators of environmental quality (Arévalo et al., 2007; Ballesteros et al., 2007 and Pinedo et al., 2007). Derna coast lack completely any brown algal species so, it could be considered a polluted site. On Egyptian J. of Phycol. Vol. 11, 2010

- 4 - 
the other hand, both of Susa and Tolmeta had 14 species at least half of them Cystoseira species so, it could be considered more pure and stable sites. Mubina and Nausheba (1992) identified 48 brown species at Karachi coast. Therefore, the study area could be considered poor of Phaeophyta.

Table (2): Distribution of brown marine algae at Derna, Susa and Tolmeta.

\begin{tabular}{|c|c|c|c|}
\hline Algae & \multicolumn{3}{|c|}{ Coasts } \\
\hline Phaeophyta & Derna & Susa & Tolmeta \\
\hline $\begin{array}{l}\text { Colpomenia sinuosa (Mertens ex Roth) Derbés ét } \\
\text { Solier }\end{array}$ & - & + & - \\
\hline Cystosiera barata (Stackhouse) C. Agardh & - & + & + \\
\hline Cystosiera cinitophylla Ercegovic & - & + & + \\
\hline Cystosiera compressa Gerloffìét Nizamuddin & - & + & + \\
\hline Cystosiera elegans Sauvageau ét Feldmann & - & + & + \\
\hline Cystosiera erica-marina (Gmelin) Naccari & - & + & - \\
\hline $\begin{array}{llllll}\text { Cystosiera discors } & \text { (Linn.) } & \text { C. } & \text { Agardh emend } \\
\text { Sauvageau } & & & & & \\
\end{array}$ & - & - & + \\
\hline Cystosiera gerloffi ( Nizamuddin) & - & + & + \\
\hline Cystosiera susanensis ( Nizamuddin) & - & + & - \\
\hline Cystosiera stricta (Montagne) Sauvageau & - & - & + \\
\hline Cystosiera mediterranea var. valiante Sauvageau & - & + & - \\
\hline Dictyopteris membranacea (Skackhouse) Batters & - & + & + \\
\hline Dictyopteris tripolitanea Nizamuddin & - & - & + \\
\hline Dictyota dichotoma (Hudson) lamouroux & - & + & + \\
\hline $\begin{array}{l}\text { Dictyota fasciola var. reoeus (J. Ag.) Feldmann } \\
\{\text { Dilophus fasciola (Roth) M.A. Howe }\}\end{array}$ & - & + & - \\
\hline Halopteris scoparia (Linnaeus) Sauvageau & - & + & - \\
\hline Padina pavonica (Linnaeus) Lamouroux Thivy & - & + & + \\
\hline Sargassum hornscuchii C. Agardh & - & - & + \\
\hline Scytosiphon lomentaria (Lyngbye) Lamouroux & - & - & + \\
\hline $\begin{array}{l}\text { Taonia atamaria (Woodward) J. Agardh var. } \\
\text { atamaria }\end{array}$ & - & + & - \\
\hline Number of genus & $\mathbf{0}$ & 7 & 6 \\
\hline Number of species & $\mathbf{0}$ & 14 & 14 \\
\hline
\end{tabular}

+: present $\quad-:$ absent

Meanwhile, Rhodophyta was represented by 17 genera and 20 species (Table 3). The richest coast of red algae was Tolmeta which had 13 species while Susa and Derna coasts had only 6 and 5 species, respectively. All of these coasts are relatively poor by Rhodophyta if compared with South Aegean Sea (Greece) which qualitatively dominated by 60 red algal taxa (Diapoulis and Tsiamis, 2007). 
Table (3): Distribution of red marine algae at Derna, Susa and Tolmeta.

\begin{tabular}{|c|c|c|c|}
\hline Algae & \multicolumn{3}{|c|}{ Coasts } \\
\hline Rhodophyta & Derna & Susa & Tolmeta \\
\hline Acrosorium uncinatum (J. Agardh) kylin & - & - & + \\
\hline Amphiroa rigida Lamouroux & - & - & + \\
\hline Botryocladia botryoides (Wulf.) Feldmann & - & - & + \\
\hline Centroceras clavulatum (C. Agardh) Montagne & + & - & - \\
\hline Chondriopsis mediterranea (Kütz.) J. Agardh & - & - & + \\
\hline Chrysmenia ventricosa (Lamour.) J. Agardh & - & - & + \\
\hline Corallina granifera (Ellis ét Solander) & - & + & - \\
\hline Corallina mediterranea & + & - & - \\
\hline Dermatolithon pustulatum (Lamouroux) Foslie & - & - & + \\
\hline Hypnea musciformis (Wulfen) Lamouroux & + & + & + \\
\hline Jania adhaerens Lamouroux & - & - & + \\
\hline Jania rubens (Linnaeus) Lamouroux & - & - & + \\
\hline Laurencia obtusa (Hudson) Lamouroux & - & + & - \\
\hline Laurencia papillosa (Forsskål) C. Agardh & - & + & + \\
\hline Liagora viscida (Forsskål) C. Agardh & - & + & - \\
\hline Lophocladia lallemandii (Montagne) Schmitz & - & + & - \\
\hline $\begin{array}{l}\text { Mesophyllum lichenoides (Ellis ét Solmander) } \\
\text { Lemoine }\end{array}$ & - & - & + \\
\hline Peyssonnelia elegella Harvey & - & - & + \\
\hline Pseudolithophyllum expansum (Philippi) Lemoine & + & - & - \\
\hline Rytiphlaea tinctoria (Clemente) C. Agardh & + & - & + \\
\hline \begin{tabular}{|c|} 
Number of genus \\
\end{tabular} & 5 & 5 & 12 \\
\hline Number of species & 5 & 6 & 13 \\
\hline
\end{tabular}

+: present $\quad-:$ absent

Table (4) illustrated that species of Chlorophyta came at the first by $34.43 \%$ while species of both Phaeophyta and Rhodophyta came next by $32.79 \%$ for each. These percentages were more or less similar to the finding of eastern Libyan coast recorded by Godeh $\boldsymbol{e t}$ al. (1992). Most of these algae were recorded also at the Turkish Urla coast (Inci et al., 2006) may be due to the same weather conditions.

Species richness index of different coasts were calculated by direct count of different marine algal species (Figure 2). Derna coast could be considered the poorest and more polluted coast of the study area where it had 12 species only (none of them belong to Phaeophyta). Meanwhile; Susa coast had 38 algal species and could be considered the relatively richest coast. Tolmeta coast had 33 different algal species. So, according to the species richness index, the purity of these coasts could be arranged as: Susa > Tolmeta > Derna. Wilhm (1975) and El-Ayouty et al. (1999) evaluated that, the decrease in number of species and the increase in number of individuals is a characteristic feature of polluted water. 
Said (2004) and Said et al. (2005) also used the species richness parameters to evaluate the purity and pollution state of different eight and four water bodies, respectively. It was mostly correlated with Chlorophyta for its dominance and variation of its taxa like the present study area. These coasts belong to Pleistocene deposits, continuously exposed to rough conditions and fluctuating cold to mild weather and generally poor in algal growth (Nizamuddin, 1985).

\begin{tabular}{|c|c|c|c|c|c|c|c|c|c|c|c|c|c|c|c|c|}
\hline \multicolumn{2}{|c|}{ Total } & \multicolumn{4}{|c|}{ Rhodophyta } & \multicolumn{4}{|c|}{ Phaeophyta } & \multicolumn{4}{|c|}{ Chlorophyta } & \multirow{3}{*}{\multicolumn{3}{|c|}{$\begin{array}{l}\text { 党 } \\
\text { a) }\end{array}$}} \\
\hline \multirow[t]{2}{*}{$\begin{array}{l}\frac{n}{2} \\
\frac{2}{2} \\
\frac{2}{2}\end{array}$} & \multirow[t]{2}{*}{$\begin{array}{l}\text { 吅 } \\
\text { 飬 }\end{array}$} & \multicolumn{2}{|c|}{ 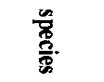 } & \multicolumn{2}{|c|}{ 产 } & \multicolumn{2}{|c|}{ 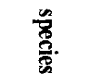 } & \multicolumn{2}{|c|}{ 曲 } & \multicolumn{2}{|c|}{ 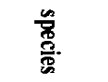 } & & & & \\
\hline & & $\therefore$ & zִ & $a^{2}$ & $z$ & $\therefore$ & zִ & $\therefore$ & ?ֶ. & $\therefore$ & $z$ & $\therefore$ & z̧ & & & \\
\hline$\rightarrow$ & $\omega$ & $\vec{\Delta}$ & $\omega$ & बे & N & 8 & 0 & 8 & 0 & تِ & - & 䍐 & - & $z$ & 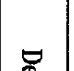 & \\
\hline ڤू̀ & है & & $\vec{s}$ & & $\Xi$ & & $\ddot{8}$ & & $\stackrel{8}{8}$ & & 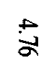 & & $\vec{\theta}$ & $\therefore$ & 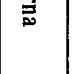 & 夈 \\
\hline N & 6 & 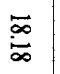 & $\Delta$ & 胥 & N & ज्ञ & $a$ & N & N & 宓 & $\bar{N}$ & ü & un & $z$ & of & $\overrightarrow{0}$ \\
\hline 产 & 蒿 & & $\approx$ & & 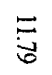 & & 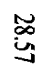 & & 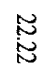 & & $\stackrel{\Xi}{0}$ & & $\begin{array}{l}\text { 文 } \\
\text { f }\end{array}$ & $\therefore$ & 10 & 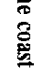 \\
\hline$\Xi$ & s & 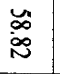 & $\Xi$ & $\vec{a}$ & 6 & 芯 & $a$ & 홍 & N & $\ddot{\check{ळ}}$ & - & 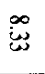 & - & $z$ & $\underline{\underline{\underline{p}}}$ & 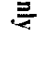 \\
\hline$\stackrel{\widetilde{\Xi}}{\dot{\oplus}}$ & $\stackrel{\vec{\exists}}{\exists}$ & & us & & $\tilde{\tilde{c}}$ & & \begin{tabular}{l}
$\mathscr{\infty}$ \\
\hdashline \\
\hdashline
\end{tabular} & & 莡 & & $\stackrel{\vec{\sigma}}{\vec{\sigma}}$ & & 흐 & $\therefore$ & $\frac{\bar{z}}{20}$ & \\
\hline ה & N & 8 & $=$ & is & - & 8 & $=$ & : & 0 & $\overline{8}$ & N & ñ & - & $z$ & $\underset{\square}{\square}$ & \\
\hline$\tilde{\tilde{s}}$ & $\ddot{\omega}$ & & 8 & & $\ddot{\infty}$ & & 8 & & 8 & & 总 & & ㅎํ & $\therefore$ & 8 & 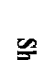 \\
\hline$n$ & N & L & - & पू & - & 8 & 0 & 8 & 0 & पै & - & us & - & $z$ & $\underline{\underline{t}} \underline{\underline{0}}$ & $\cong$ \\
\hline$\underset{\tilde{\infty}}{\tilde{\infty}}$ & $\tilde{\omega}$ & & in & & $\ddot{\infty}$ & & 8 & & $\stackrel{8}{8}$ & & 芯 & & $\vec{g}$ & $\therefore$ & 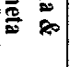 & 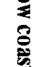 \\
\hline$\Xi$ & $\sim$ & ह & - & 胥 & - & 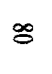 & $\infty$ & $\vec{E}$ & en & z & - & 志 & - & $z$ & $\overrightarrow{0}$ & 产 \\
\hline ప్టे & $\overrightarrow{\vec{s}}$ & & « & & $\ddot{\infty}$ & & t & & 芯 & & 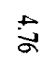 & & $\overrightarrow{8}$ & $\therefore$ & $\frac{20}{20}$ & \\
\hline+ & $\rightarrow$ & $\widetilde{n}$ & - & $\approx$ & - & вे & $=$ & 8 & $=$ & $\vec{\sim}$ & $\omega$ & $\leadsto$ & $\omega$ & $z$ & \multirow{2}{*}{ 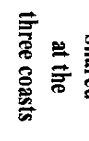 } & \\
\hline ふूँ & 总 & & in & & $\ddot{\infty}$ & & 8 & & 8 & & 胥 & & $\ddot{\infty}$ & $\therefore$ & & \\
\hline \multirow{2}{*}{ 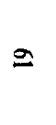 } & \multirow{2}{*}{$\tilde{\sigma}$} & \multicolumn{2}{|c|}{ 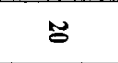 } & \multicolumn{2}{|c|}{$\Xi$} & \multicolumn{2}{|c|}{$\approx$} & \multicolumn{2}{|c|}{ 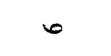 } & \multicolumn{2}{|c|}{$\approx$} & \multicolumn{2}{|c|}{$\varpi$} & $z$ & \multirow{2}{*}{\multicolumn{2}{|c|}{$\overrightarrow{\underline{\underline{\underline{\underline{e}}}}}$}} \\
\hline & & \multicolumn{2}{|c|}{$\stackrel{\vec{N}}{\mathbb{U}}$} & \multicolumn{2}{|c|}{ 壱 } & \multicolumn{2}{|c|}{ 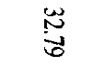 } & \multicolumn{2}{|c|}{ 䓵 } & \multicolumn{2}{|c|}{$\underset{t}{\omega}$} & \multicolumn{2}{|c|}{ 岕 } & $\therefore$ & & \\
\hline
\end{tabular}




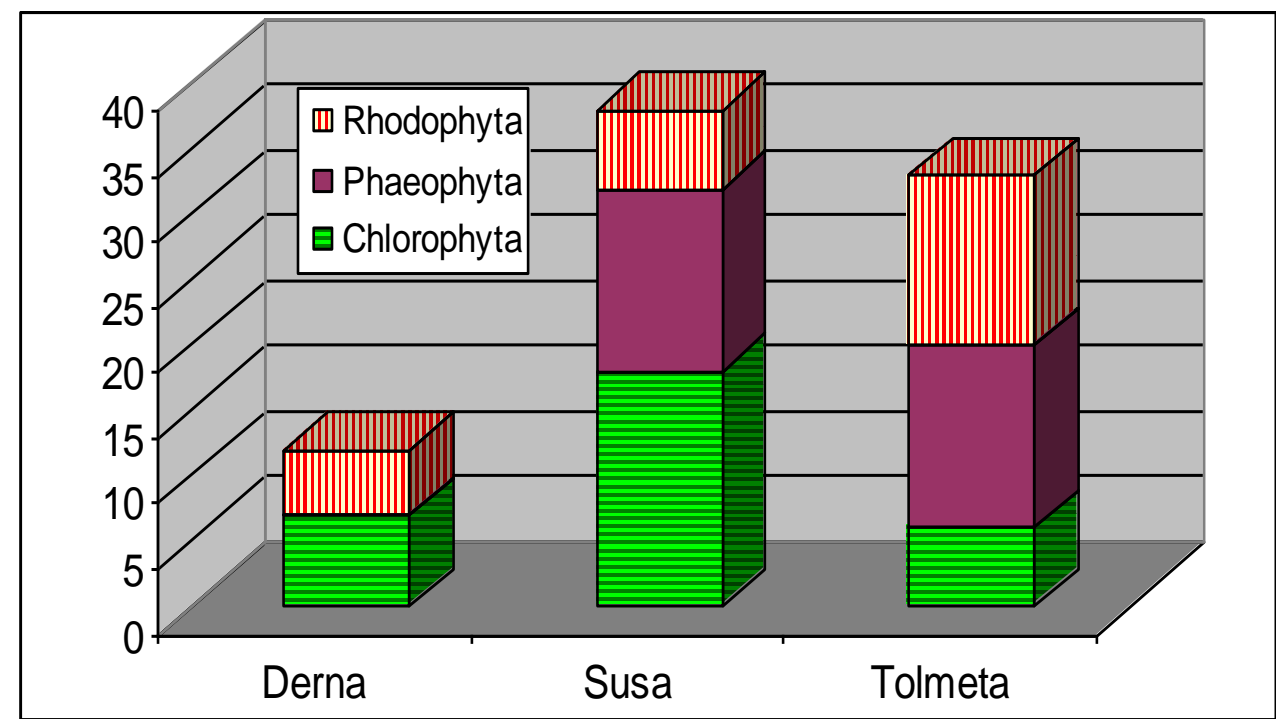

Figure (2): The presence of different marine algal groups at Derna, Susa and Tolmeta coasts.

There are some marine algal species found only at every coast while, others were shared at two coasts (Table 4). Just four $(6.56 \%)$ algal species (3 genera) were present only at Derna coast (the relatively poorest coast). Twenty two (36.07\%) marine algal species (9 genera) found only at Susa coast (the relatively richest coast). Seventeen (27.87\%) marine algal species (12 genera) found only at Tolmeta coast (the relatively moderate coast). Just two (3.28\%) algal species (2 genera) were shared at Derna coast and both of Susa and Tolmeta coasts while ten (16.39\%) algal species (7 genera) were common in both coasts of Susa and Tolmeta. Surprising was that, there are only four (16.39) algal species (4 genera) shared at the three coasts; three species of them belonged to Chlorophyta (Anadyomene stellata, Dasycladus vermicularis and Halimeda tuna) and just one species of Rhodophyta (Hypnea musciformis). Godeh et al. (2009) reported that, Tobruk had a rich coast characterized by thirty six species of different marine algae at relatively similar area and conditions.

It seemed more convenient to produce more one matrix to evaluate the similarity parameters between Derna, Susa and Tolmeta coasts according to Chlorophyta, Phaeophyta, Rhodophyta and Total algae using the equation of Sorenson (1948) depending on the presence or absence of different taxa. The degree of similarity among green species recorded the highest percentages especially between Derna and Tolmeta (61.54\%).

Of course there was no similarity between brown species of Derna and any other coasts due to the complete absence of Phaeophyta while it was relatively 
high $(59.26 \%)$ in Susa and Tolmeta coasts (Table 5). The degree of similarity between red species were relatively low (around 20\%) in all coasts. Logically, due to the complete absence of Phaeophyta of Derna, the degrees of similarity among all algal species were also relatively low between all coasts.

Table (5): Similarity between Derna, Susa and Tolmeta coasts according to Chlorophyta (above diagonal) and Phaeophyta (below diagonal).

\begin{tabular}{|c|c|c|c|}
\hline Coasts & Derna & Susa & Tolmeta \\
\hline Derna & $100 \%$ & $\mathbf{4 0}$ & $\mathbf{6 1 . 5 4}$ \\
\hline Susa & $\mathbf{0 . 0 0}$ & $100 \%$ & $\mathbf{3 3 . 3 3}$ \\
\hline Tolmeta & $\mathbf{0 . 0 0}$ & $\mathbf{5 9 . 2 6}$ & $100 \%$ \\
\hline
\end{tabular}

The highest value $(57.14 \%$ ) was recorded between Susa and Tolmeta (Table 6). Said (2004) and Said et al. (2005) evaluated the similarity parameters according to different algal groups between eight and four different water bodies, respectively.

Table (6): Similarity index between Derna, Susa and Tolmeta coasts according to Rhodophyta (above diagonal) and Total algae (below diagonal).

\begin{tabular}{|c|c|c|c|}
\hline Coasts & Derna & Susa & Tolmeta \\
\hline Derna & $100 \%$ & $\mathbf{1 8 . 1 8}$ & $\mathbf{2 2 . 2 2}$ \\
\hline Susa & $\mathbf{2 4}$ & $100 \%$ & $\mathbf{2 1 . 0 5}$ \\
\hline Tolmeta & $\mathbf{2 6 . 6 7}$ & $\mathbf{5 7 . 1 4}$ & $100 \%$ \\
\hline
\end{tabular}

The R/P ratio was 0.43 and 0.93 at Susa and Tolmeta coasts respectively, which lower than those of subtropical like, Turkish coast (2.0) which recorded by Güven and Özting (1971), the eastern coast of Libya (2.05) which recorded by Godeh $\boldsymbol{e t}$ al. (1992) and Tobruk coast (1.45) which recorded by Godeh $\boldsymbol{e t}$ al. (2009). The R/P ratio of Derna coast could not calculated due to the absence of Phaeophyta. This intertidal zone and rocky coasts always exposed to low tides and the collection of algae was done at "stable water" with agreement of same conditions at Robe coast of south Austria (Dawes, 1998). Rhodophyta exceeded brown and green algae at temperate and tropical regions only (Lee, 1999). The value of R/P ratio in Rhodes Island and south Agean Sea (Greece) is 3.5 and 3.2 respectively, suggested a warm-temperate aspect of macroalgal flora (Diapoulis and Tsiamis, 2007 and Tsiamis et al., 2007).

\section{Acknowledgement}

This work was supported by research and consultancies center of Garyounis University. 


\section{References}

Aleem, A. (1993). ( $2^{\text {nd }}$ ed.) The marine algae of the Alexandria, Egypt.

Arévalo, R.; Pinedo, S. and Ballesteros, E. (2007). Changes in the composition and structure of Mediterranean rocky-shore communities following a gradient of nutrient enrichment: descriptive study and test of proposed methods to assess water quality regarding macroalgae. Marine pollution Bulletin, 55: 104-113.

Ardissone, F. (1893). Note alla Phycologia mediterranea. Rend. R. Inst. Lombardo Sci. Lett. Ser., 2 (26): 674-690.

Ballesteros, E.; Torras, X.; Pinedo S.; Garcia M.; Mangialjo, L. and Torres, M. (2007). A new methodology based on littoral community cartography for the implementation of the European Water Framework Directive. Marine pollution Bulletin, 55: 172-180.

Burrows, E. (1991). Seaweeds of the British Isles. Volume 2. Chlorophyta. London: British Museum (Natural History).

Critchley, A.; Gillespie, R. and Rotman, K. (1998). Seaweed resources of South Africa. Pp. 413-425. In: Critchley A. T. Ohno M (eds), Seaweed resources of the world. Japan International Cooperation Agency, Japan.

David, B.; Luigi, P. and Francesco, C. (2004). A Comparison Among Assemblages in Areas Invaded by Caulerpa taxifolia and C. racemosa on a Subtidal Mediterranean Rocky Bottom. Marine Ecology, 25 (1): 1-13.

Dawes, C. (1998): Marine Botany. John Wiley and Sons, New York.

Diapoulis, A. and Tsiamis, K. (2007). Marine flora and vegetation of South Agean Sea (Greece). Proceeding of the $3^{\text {rd }}$ Mediterranean symposium on marine vegetation. Marseilles. 27-29 March 2007 - 263-264.

Diaz-Valdes, M.; Abellan, E.; Izquierdo, A. and Ramos-Espla, A. (2007). Evaluation of the macroalgae communities in the Valencian rocky coasts (SE Spain) for the European Water Framework Directive (WFD). Proceeding of the $3^{\text {rd }}$ Mediterranean symposium on marine vegetation. 2729 March 2007 - Marseilles. 265-266.

El-Ayouty, Y.; El-Essawy, A. and Said, A. (1999). The assessment of water quality of Enan and El-Abassa ponds, Egypt. Acta Hydrobiol., 41 ( 2) 117137.

El-Fatemi, A. (2008). Study of the effective of some brown algal species extractions (order: Dictyotales) against pathogenic fungi. M. Sc. Thesis, Botany Department, Faculty of Science, Garyounis University, Libya. (in Arabic).

El-Gahmy, H. (2007). Study of the effective of some green algal species extractions (order: Ulvales) against pathogenic bacteria and fungi. M. Sc. Thesis, Botany Department, Faculty of Science, Garyounis University, Libya. (in Arabic). 
Ely, R.; Supriya, T. and Naik, C. (2004). Antimicrobial activity of marine organisms collected off the coast of south East India. J. Exp. Biol. and Ecol., 309: 121 - 127.

Faulkner, D. (2002). Marine natural products. Natural product Reports, 19: 1-48.

Godeh, M.; Nizamuddin, M. and El-Menifi, F. (1992): Marine algae from eastern coast of Libya (Cyrenaica). Pak. J. Bot., 24(1): 11-21.

Godeh M.; El-Menifi, F. and Said, A. (2009). Marine algae of Tobruk and Ain Ghazala coasts, Libya. Journal of Science and its Applications. Faculty of Science, Garyounis University Press, Benghazi, Libya, 3 (1) 42-55.

Güven, K. and Özting, F. (1971): Über die marinen Algen an den küsten der Türkei. Bot. Mar., 14: 121-128.

Haefner, B. (2003). Drugs from the deep. Drug Discovery Today. 8(12): 536.

Hafez, S.; El-Manawy, I.; El-Ayouty, Y.; El-Adel, H. and Eraqi, I. (2005). Phytochemical investigation and antimicrobial activity of Ulva lactuca (L.). Bull. Faculty of Science, Zagazig University, 27: 27-40.

Inci, T.; Bilge H., Çadircl, D. and Atakan, S. (2006). Antimicrobial Activity of the Extracts of Marine Algae from Coast of Urla (Izmir, Turkey). Turk. $J$. Biol., 30: 171-175.

Lee, R. (1999). Phycology. Cambridge: UK. Cambridge University Press. $3^{\text {rd }}$ ed.

Lima-Filho, J.; Carvalho, A. and Freitas, S. (2002): Antimicrobial activity of extracts of six macroalgae from the Northeastern Brazilian Coast. Brazilian Journal of Microbiology, 33: 311-313.

Linda, E. and Lee, W. (2000). Algae. University of Wisconsin. Prentice Hall. Upper Saddle River, N.J .07458. USA.

Mubina, B. and Nausheba, K. (1992). Taxonomical revision and some biological observations on scytosiphonales (Phaeophyta) of Karachi coast. Pak. J. Bot., 24(1): 22-30.

Nizamuddin, M. (1985). A new species of Cystoseira C. Ag. (Phaeophyta) from the eastern Part of Libya. Nova Hedwigia. Band 42. Braunschwig. J. Cramer pp.119-125.

Nizamuddin, M. and El-Menifi, F. (1993). A new species of the genus Codium (Chlorophyta-Codiales) from the eastern coast of Libya. Pak. J. Bot., 25(2): 208-214.

Nizamuddin, M. and Godeh, M. (1989). Stypopordium tubruqense (Phaeophyta, Dictyotales), a new species from the Mediterranean Sea. Willdenowia, 18: 603-608.

Nizamuddin, M. and Godeh, M. (1990a). A first record of the genus Cottoniella Børgesen (Ceramiales, Rhodophyta) from Libya. Pak. J. Bot., 25(1): 24-35.

Nizamuddin, M. and Godeh, M. (1990b). Studies on the new species of Cottoniella from the coast of Libya. Pak. J. Bot., 25(1): 36-47.

Nizamuddin, M. and Godeh, M. (1990c). Studies on the genera Chaetomorpha Kütz. and Rhizoclonium Kütz. (Cldophorales-Cladophoraceae) from the 
Libyan coast. National Herbarium Uni. Al-Fateh, Tripoli. Bull. ULT, 2: 1137.

Nizamuddin, M. and Godeh, M. (1993). Observations on Taonia atomaria F. ciliate (Lamour.) Nizamuddin. Pak. J. Bot., 25(2): 199-207.

Nizamuddin, M.; West, J. and Menez, E. (1979). A list of marine algae from Libya. Bot. Mar., 22: 465-476.

Pampanini, R. (1931). Prodromo della Cirenaica. Algae, 1-40.

Piazzi, L.; Meinez, A.; Verlaque, M.; Ali, B.; Antolic, B.; Argyrou, M.; Balata, D.; Ballesteros, E.; Calvo, S.; Cinelli, F.; Cirik, S.; Cossu, A.; D'Archino, R.; Djellouli, S.; Javel, F.; Lanfranco, E.; Mifsud, C.; Pala, D.; Panayotidis, P.; Peirano, A.; Pergent, G.; Petrocelli, A.; Ruitton, S.; Zuljvic, A. and Ceccherelli, G. (2005). Invasion of Caulerpa racemosa var. cylindracea (Caulerpales, Chlorophyta) in the Mediterranean Sea: an assessment of the spread. Cryptogam. Algol., 26: 189-202.

Pinedo, S.; Garcia, M.; Satta, M.; Torras, X. and Ballesteros, E. (2007). Rocky-shore communities as indicators of water quality: a case study in the Northern Mrditerranean. Marine pollution Bulletin, 55: 126-135.

Ruoe'rez, P. and Saura-Calixto, F. (2001). Dietary fiber and physicochemical properties of edible Spanish seaweeds. Europe. J. of Food Res. and Tech., 212: 349-354.

Said, A. (2004). Ecophysiological studies on the response of some freshwater algae to pollution. Ph. D. Thesis, Botany Department, Faculty of Science, Zagazig University, Egypt.

Said, A.; El-Ayouty, Y.; Hussien, A. and El-Shafei, M. (2005). Preliminary studies on epiphytic algae associated with some dominated macrophytes in water habitats. Bull. Faculty of Science, Zagazig University, Egypt, 27: 87108.

Sorenson, T. (1948). A method of establishing group of equal amolitude in plant sociology based on similarity of species content. Det. Kong. Danske Vidensk. Biol. Skr. (Copenhagen). 5(4): 1-34.

Tsiamis, K.; Panayotidis, P. and Montesanto, B. (2007). Contribution to the study of the marine vegetation of Rhodes Island (Greece). Proceeding of the $3^{\text {rd }}$ Mediterranean symposium on marine vegetation. 27-29 March 2007 Marseilles. 190-196.

Wilhm, J. (1975). Biological indicators of pollution- In: Whitton, B. A. (ed.), River ecology. - Blackwell. Oxford: pp. 375-400. 


\section{الطحالب البحرية بشواطئ درنة،سسوسة و طلميثةـ ليبيا.

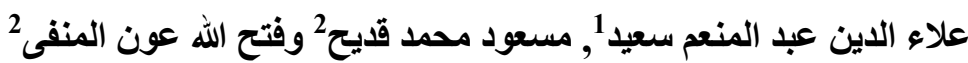

\author{
"قفم النبات، كلية العلوم، جامعة/لزقازيق- مصر
} \\ 2قنسم النبات، كلية العلوم، جامعة قار بونس، بنغازى- ليبيا}

استهدفت الدراسة تجميع وتعريف الطحالب البحرية النامية على شواطئ درنة و سوسة وطلميثة

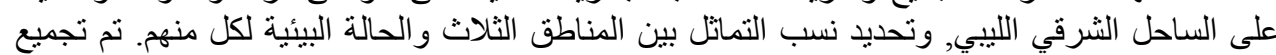

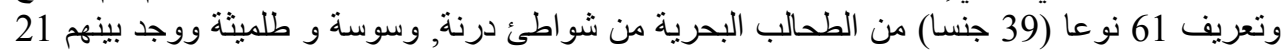

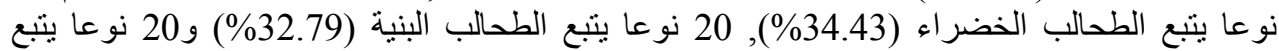

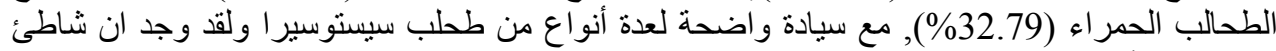

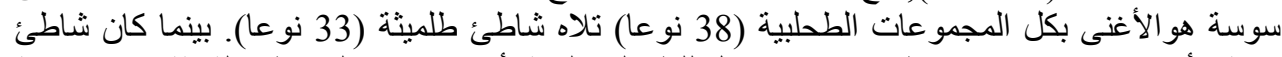

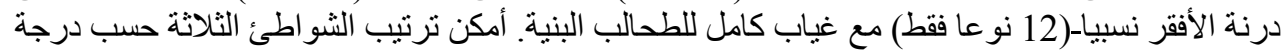

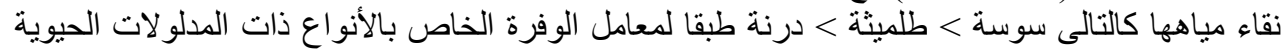

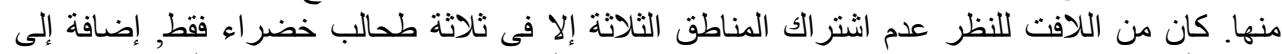

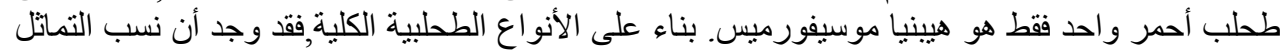

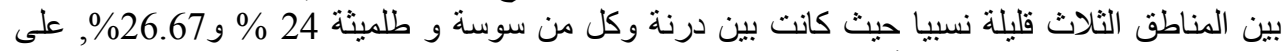
التو الي. بينما كانت نسبة التماتل أكبر نسبيا (57.14\%) بين سوسة و طلميثة ديثة. 